\title{
Proximate Composition of Traditional Turkish Stuffed Meatballs Produced with Rainbow Trout (Oncorhynchus mykiss Walbaum, 1792) Mince and Determination of its Colour and Sensory Quality during Frozen Storage $\left(-18^{\circ} \mathrm{C}\right)$
}

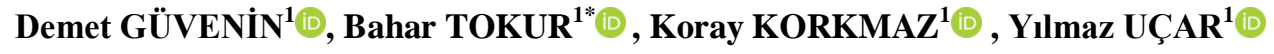 \\ ${ }^{1}$ Ordu University, Fatsa Faculty of Marine Sciences, Ordu University, 52400, Ordu, Turkey. \\ *Corresponding Author: baharorhun@gmail.com
}

\begin{abstract}
Received 18 December 2020; Accepted 19 April 2021; Release date 01 September 2021.
How to Cite: Güvenin, D., Tokur, B., Korkmaz, K., \& Uçar, Y. (2021). Proximate composition of traditional Turkish stuffed meatballs produced with rainbow trout (Oncorhynchus mykiss Walbaum, 1792) mince and determination of its colour and sensory quality during frozen storage $\left(-18^{\circ} \mathrm{C}\right)$. Acta Aquatica Turcica, 17(3), 361-375. https://doi.org/10.22392/actaquatr.842738
\end{abstract}

\begin{abstract}
The nutritional value of stuffed meatballs made with minced rainbow trout rather than red meat in the stuffing was investigated, as well as color variations ( $\mathrm{L}^{*}, \mathrm{a} *$, and $\mathrm{b} *$ ) and sensory quality, using two different cooking methods (boiling and frying) on samples stored in the freezer $\left(-18{ }^{\circ} \mathrm{C}\right)$. As a result of this research, the moisture, the crude ash, the lipid, and the crude protein contents of stuffed meatballs produced with rainbow trout were found as $\% 58.25 \pm 0.93, \% 2.01 \pm 0.05$, $\% 5.28 \pm 0.29$, and $\% 7.69 \pm 0.08$, respectively. The content of total saturated fatty acids composition $\left(\sum \mathrm{SFA}\right)$, total monounsaturated fatty acids composition ( $\sum$ MUFA), and total polyunsaturated fatty acids composition ( $\sum$ PUFA) was found to be $12.52 \pm 0.23 \%, 39.11 \pm 1.27 \%$, and $43.73 \pm 1.98 \%$, respectively. The atherogenic (AI) and thrombogenic indexes (TI) for dietary factors associated with cardiovascular disease were found to be 0.10 and 0.25 , respectively. In the evaluation of color $(\mathrm{L} *, \mathrm{a} *$, and $\mathrm{b} *$ ) of frozen samples, $\mathrm{L} *$ (black-white) and $\mathrm{b} *$ (blue-yellow) values in all groups (raw, boiled, and fried) increased significantly at the end of storage compared to the initial value $(\mathrm{p}<0.05)$. Following frying and boiling, the $*$ (green-red) values of the frozen-stored samples decreased significantly $(\mathrm{p}<0,05)$. Sensory quality was assessed in this study using two cooking methods: boiling and fried, both of which are common serving methods for stuffed meatballs. Although a significant decrease was detected in all sensory quality parameters of samples during frozen storage, it was determined that it did not reach the unacceptable limit at the end of storage.
\end{abstract}

Keywords: Proximate Composition, Frozen Storage, Stuffed Meatballs, Rainbow Trout, Color

Gökkuşağı Alabalık (Oncorhynchus mykiss Walbaum, 1792) Kıyması ile Üretilmiş Geleneksel Türk İçli Köftesinin Besinsel Komposizyonu ve Dondurularak Depolama Boyunca $\left(-\mathbf{1 8}^{\circ} \mathrm{C}\right)$ Renk ve Duyusal Kalitesinin Belirlenmesi

Özet

$\mathrm{Bu}$ çalışmada, iç harcında kırmızı et yerine gökkuşağı alabalık kıyması kullanılarak üretilen içli köftelerin besinsel komposizyonu belirlenmiş ve dondurularak depolanan $\left(-18^{\circ} \mathrm{C}\right)$ örneklere iki farklı pişirme metodu uygulanarak (haşlama ve kızartma) renk ( $\mathrm{L}^{*}, \mathrm{a}^{*}$ ve $\mathrm{b}^{*}$ ) ve duyusal kalitesinde meydana gelen değişimler incelenmiştir. Araştırma sonucunda, üretilen gökkuşağı alabalıklı içli köftelerin nem, ham kül, lipit ve ham protein düzeyi sirasıyla $\% 58,25 \pm 0,93, \% 2,01 \pm 0,05$, $\% 5,28 \pm 0,29$ ve $\% 7,69 \pm 0,08$ olarak bulunmuştur. Gökkuşağı alabalıklı içli köftelerin toplam doymuş yağ asitleri ( $\sum$ SFA), toplam tekli doymamış yağ asitleri ( $\left(\right.$ MUFA) ve toplam çoklu doymamış yă asitleri ( $\sum$ PUFA) miktarları sırasıyla $\% 12,52 \pm 0,23, \% 39,10 \pm 1,27$ ve $\% 43,73 \pm 1,98$ olarak saptanmıştır. Kardiyovasküler hastalıkla ilişkili diyet faktörleri için Aterojenik (AI) ve trombojenik indeksler (TI) sırasıyla 0,10 ve 0,25 olarak bulunmuştur. Dondurarak depolanan örneklerin renk (L*, a* ve $b^{*}$ ) değerlendirmesinde, tüm gruplarda (ham, haşlanmış ve kızartılmış) $L^{*}$ (siyah-beyaz) ve b* (mavi-sarı) değerlerinin depolama sonunda başlangıç değerine göre önemli oranda arttığı $(p<0,05)$ bulunmuştur. Dondurarak depolanmış örneklerin kızartılma ve haşlama işleminden sonra a* (yeşil-kırmızı) değerlerinin ise önemli oranda azaldığı bulunmuştur $(\mathrm{p}<0,05)$. Bu çalışmada duyusal kalite, içli köftelerin geleneksel sunum formları olan kızartma ve haşlama olarak iki farklı pişirme metodu ile değerlendirilmiştir. Dondurarak depolama boyunca örneklerin pişirme öncesi, kızartma ve haşlama sonrası tüm duyusal kalite parametrelerinde önemli bir azalma saptansa da depolamanın sonunda tüketilmezlik sınırına ulaşmadığı belirlenmiştir.

Anahtar Kelimeler: Besin Komposizyonu, Dondurarak Depolama, İçli Köfte, Gökkuşağı Alabalığı, Renk 


\section{INTRODUCTION}

Bulgur, which is one of the first processed foodstuffs in the world, has been the main ingredient in many dishes of the Turkish people in Anatolia for 3-4 thousand years. There are many types of dishes made using bulgur such as pilav, raw meatballs, sour meatballs, stuffed meatballs, salads, soups, and as a meat substitute in vegetarian dishes (Yaman, 1992; Yu and Kies, 1993; Işık, 2006; Dönmez et al., 2004). Now, it is widely consumed not only in Turkey but also in Greece, Cyprus, the Middle East, North Africa, and East Europe (Basaran, 1999).

Traditional Turkish stuffed meatballs are kinds of meatballs that are made from bulgur and filled in with dough. Its name is the original "Kibbe" from Arab cuisine. This dish was called Syriac Torpedo by the British on Syrian territory during World War II. This dish is made mainly in Adana, Osmaniye, Kahramanmaraş, Elazı̆̆, Malatja, Mardin, Diyarbakır, Hatay, Gaziantep, Sanlıurfa and Adıyaman, and derived from the Persian term köfte Eren and Sezgin, 2017; Yüzgül, 2019).

Stuffed meatballs are prepared in a variety of ways around the country, with variations owing to the ingredients used in the dough and filling preparation. Ground meat with or without tail fat (depending on region), tomato paste, onion, parsley, and spices are the main filling materials for stuffed meatballs (walnuts can also be put on demand). Since it is complex and time-consuming to cook, it is no longer a regular dinner in Turkey, but rather a special occasion meal (Ball, 2013). There are two ways to prepare stuffed meatballs. The first is the boiling process, which is commonly used in large quantities due to its lightness. It unquestionably has a spot at the table when it comes to hosting special events such as celebrations, promises, weddings, and henna evenings. The second method is frying, which is more common in big cities, especially in hotels and restaurants, due to the possibility of the meatballs being scattered in the boiling method. The second is frying. It is made in big cities, especially in hotels and restaurants. Frying is more preferred in such places because of the possibility of the meatballs being scattered in the boiling method (Arslanhan, 2014). In a study on consumer preferences of soup, appetizers, main dishes and desserts offered to consumption in local Turkish cuisine, it is stated that stuffed meatballs are the most preferred food by customers among many appetizers (Güler et al., 2016). The presence of ready-to-cook stuffed meatballs from different brands in supermarkets' prepared ready-to-eat foods category is one of the most important indicators of consumer appetite for it.

Changes in consumer behavior, heavy workload conditions, a lack of time to prepare, and a need to eat certain meals outside of season have mostly led to the widespread use of frozen ready-to-cook or ready-to-eat foods (Cuneo, 1998). As the sector's production quality has improved, frozen ready meals (cook or eat form) have started to be offered as an alternative to home meals (Sarasin, 2000).

It is stated that the most critical and frequent challenge of human beings in the developed and changing world is sufficient and malnutrition. In this regard, animal foods have an important role due to meat protein and its biological properties. According to the data of the World Health Organization (WHO), 1 gram protein for each kilogram of a healthy person's body weight per day should be consumed and $42 \%$ of it should be of animal origin (; Saygin and Demirbaş, 2018). Even though modern Turkish cuisine represents local changes, it primarily consists of dishes based on meat, vegetables, and pastries. Seafood-based meals are more common in coastal areas and in areas where freshwater supplies, such as lakes and streams, are abundant. Fresh seafood intake in Turkey is very modest as compared to red meat and cereals in other countries (Şengör and Ceylan, 2018). According to TUIK (2020) data; the annual average fish consumption per person varies around $6.3 \mathrm{~kg}$. However, it is a well-known fact that fish and their products are much more important in terms of health and flavor than other animal-based foods in the current time (Çolakoğlu, 2004). Therefore, including fishcontaining products in diets not only enhances food quality but also increases fish intake. Furthermore, there is a high potential for adding fish-containing items as a seasoning to ready-to-eat meals in the form of "ready to serve" or "ready to eat" that are traditionally popular (Reddy et al., 2012).

Aramouni et al. (2001) studied stuffed meatballs (named as kubbee) made from ground beef (10\% fat), bulgur wheat, and spices with a filling of barbecue sauce and evaluated their shelf-life of raw and precooked vacuum packaged product during 180 days of storage at $-18{ }^{\circ} \mathrm{C}$. Khazaal (2004) patented a food described as stuffed meatballs. Güler et al. (2016) investigated stuffed meatballs in terms of consumer's preference for a favorite local food menu composed of regionally known appetizers and Yağmur et al. (2014) studied the proximate composition of stuffed meatballs produced traditionally in 
Adana. Although fish-containing products were studied for other dishes prepared from bulgur such as çiğ köfte (Kaba et al., 2014; Ozturk et al., 2016), no studies have been found on the production of stuffed meatballs with fish and their quality changes during frozen storage.

The purpose of this study was to determine the proximate composition, color changes $\left(\mathrm{L}^{*}, \mathrm{a}^{*}\right.$, and b*), and sensory quality of stuffed meatballs, a traditional Turkish cuisine, produced using rainbow trout mince as a filling ingredient, and their sensory quality during frozen storage $\left(-18{ }^{\circ} \mathrm{C}\right)$.

\section{MATERIAL and METHODS}

\section{Material}

In the study, the cage-cultured rainbow trout (Oncorhynchus mykiss), $1.25 \pm 0.09 \mathrm{~kg}$ in weight and $37.83 \pm 1.83 \mathrm{~cm}$ length used as fish material, were obtained from a local company in Perşembe, Ordu. Other ingredients used in making stuffed meatballs (onion, bulgur, salt, black pepper, farina, flour, tomato paste, parsley, and sunflower oil) were obtained from a local market.

\section{Methods}

\section{Preparing stuffed meatballs with rainbow trout mince}

The stuffed meatballs with rainbow trout were developed by taking into account the various recipes used for traditionally produced stuffed meatballs, and they were boiled and introduced to six trained panelists for hedonic testing. In the hedonic test, the stuffed meatballs were evaluated using a 1-3point scale for odor, smell, and taste. These scores are defined as (1) I don't like it at all, (2) I like it, and (3) I like it very much (Doloksaribu et al., 2015). The stuffed meatballs with rainbow trout that received the highest score in the hedonic test were formulated following the panelists' recommendations, and two formulations were made, namely stuffing materials and outer shell. (Tables 1 and 2).

\section{Stuffing materials}

The ratio (\%) of stuffing materials of stuffed meatballs with rainbow trout is given in Table 1.

Table 1. The proportions of the materials used in the preparation of the stuffed meatballs with rainbow trout (\%)

\begin{tabular}{lc}
\hline \hline Stuffing materials & \% \\
\hline Rainbow trout mince & 34.22 \\
Onion & 47.42 \\
Salt & 0.33 \\
Black pepper & 0.53 \\
Parsley & 7.47 \\
Sunflower oil & 10.03 \\
\hline \hline
\end{tabular}

The harvested rainbow trout from cages were beheaded, gutted, washed, filleted, and cut into small cubes immediately after killing and transferred to the Processing Technology Laboratory of the Faculty of Fatsa Marine Science in a foam box containing crushed ice within 1 hour. After the onions and parsley were picked and washed, they were minced in the Ortimax $700 \mathrm{~W}$ food processor. The onions were roasted in sunflower oil until they turn pink, and then the minced rainbow trout fillets were added. When the water of the mixture was absorbed, parsley, salt, and black pepper were added and cooked for a few more minutes (Figure 1). 


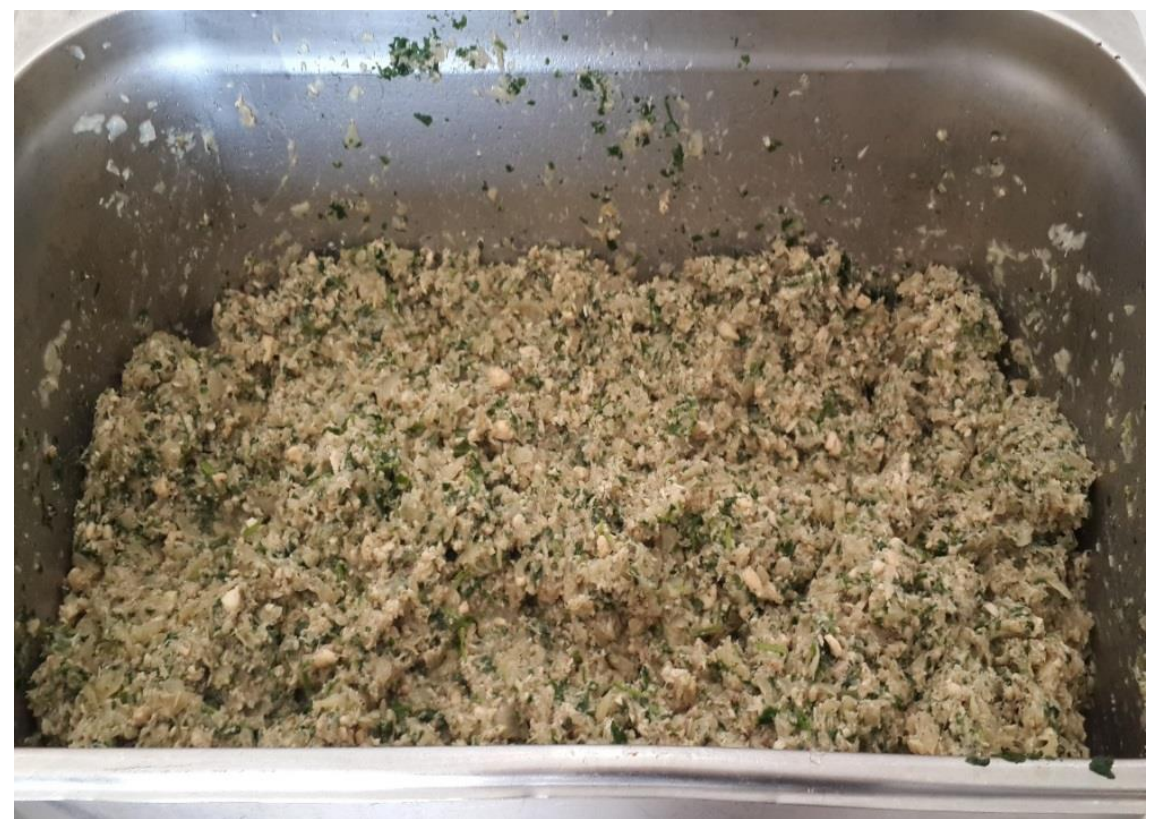

Figure 1. Cooked stuffing materials

\section{The outer shell of stuffed meatballs}

The proportions (\%) of the outer shell materials used in the preparation of stuffed meatballs with rainbow trout are shown in Table 2.

Table 2. The proportion of outer shell materials used in the preparation of stuffed meatballs with rainbow trout (\%)

\begin{tabular}{lc}
\hline Materials of the outer shell & $\boldsymbol{\%}$ \\
\hline Bulgur & 52.84 \\
Farina & 13.48 \\
Flour & 12.57 \\
Salt & 2.71 \\
Tomato paste & 18.40 \\
\hline \hline
\end{tabular}

Boiled water $(2 / 3$ ratio, v/w) was added to the bulgur and farina mixture, and it was kept at room temperature until the water was absorbed by the bulgur and farina. After the bulgur and farina sucked the water, the other ingredients; flour, salt, and tomato paste were added and the whole mixture was mixed homogeneously. The mixture was kneaded by hand until it was shaped (Figure 2).

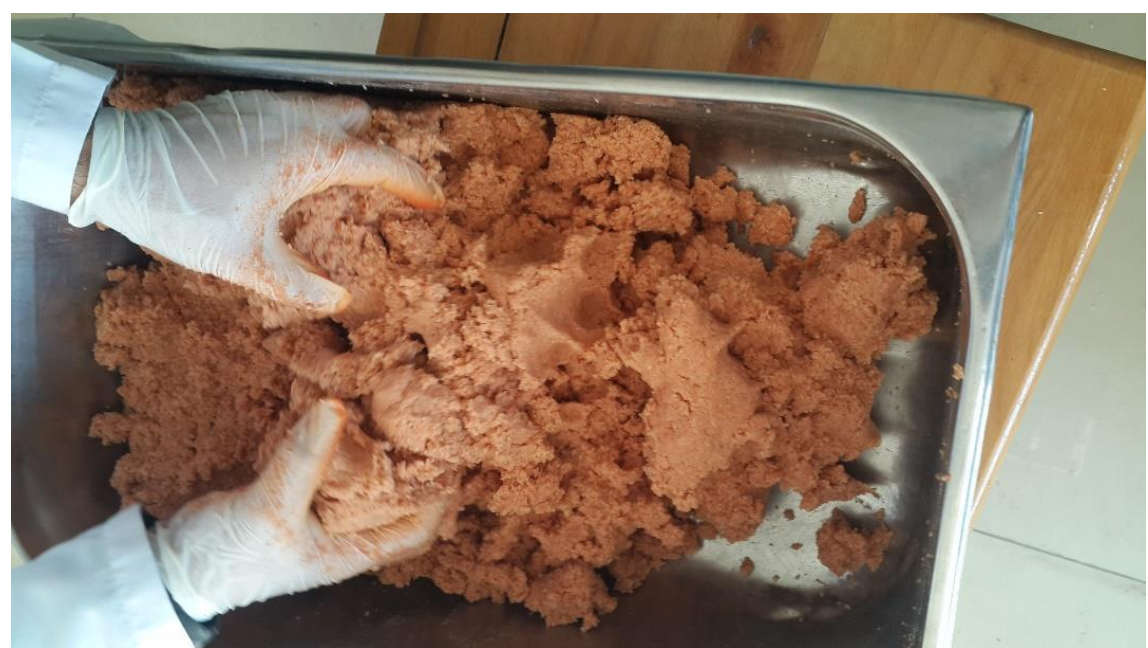

Figure 2. Kneading of the outer shell of stuffed meatballs with rainbow trout 
To produce stuffed meatballs in equal diameter and size, the meat grinder (EMP.12.01. P type $220 \mathrm{~W})$ was equipped with stuffed meatball-making apparatus. The prepared bulgur mixture was passed through a meat grinder and cut into $7 \mathrm{~cm}$ lengths each (Figure 3 and Figure 4).

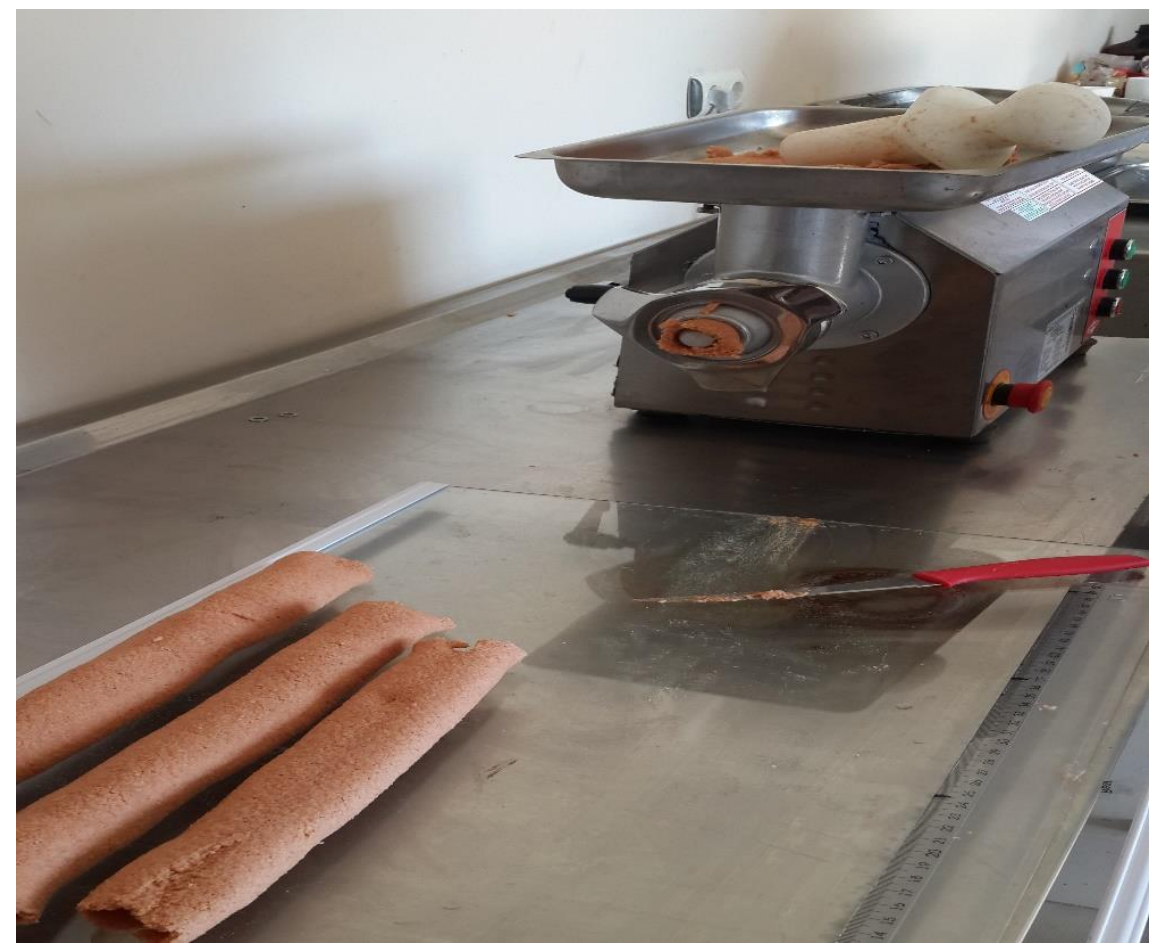

Figure 3. Cylindrically shaped outer shell passing through stuffed meatballs apparatus.

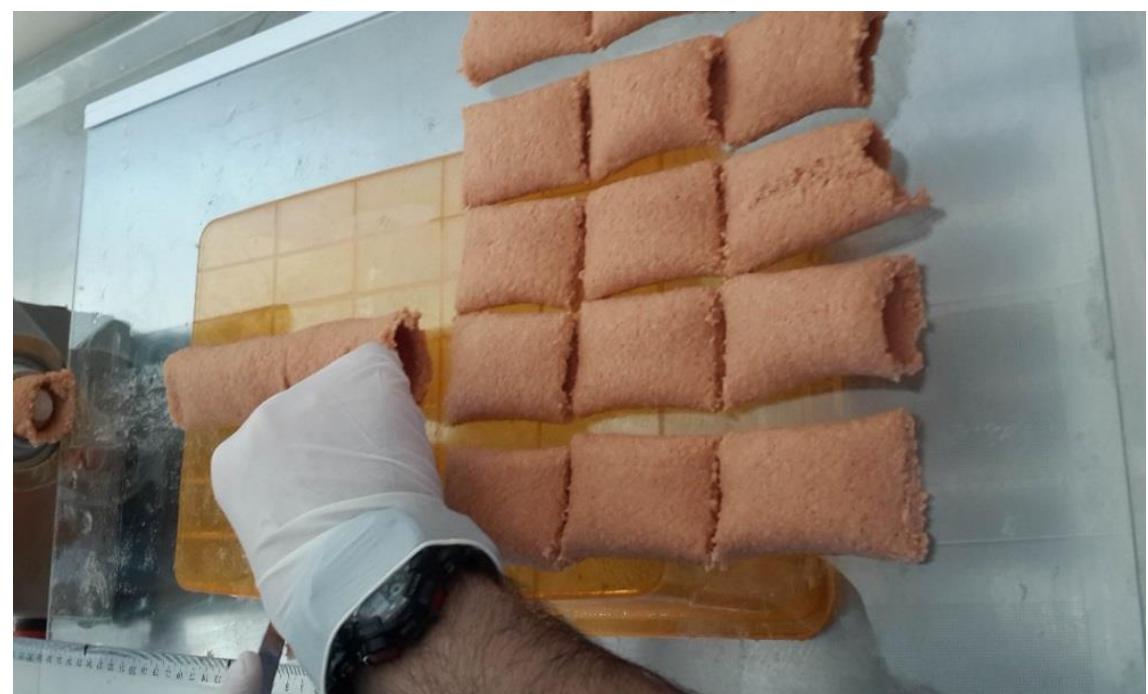

Figure 4. Ready to fill shaped outer shell of stuffed meatballs with rainbow trout.

The previously cooked stuffed materials were filled into the outer shell that was ready to be filled, and the ends of the meatballs were covered and made ready to be frozen. The total weight of the produced stuffed meatballs was determined as $54.87 \pm 2.53 \mathrm{~g}$. After the stuffed meatballs were placed on metal trays and frozen at $-40^{\circ} \mathrm{C}$, the packaged products in refrigerator bags were stored at $-18^{\circ} \mathrm{C}$, and the changes in color and sensory quality were investigated by monthly sampling (Figure 5) 


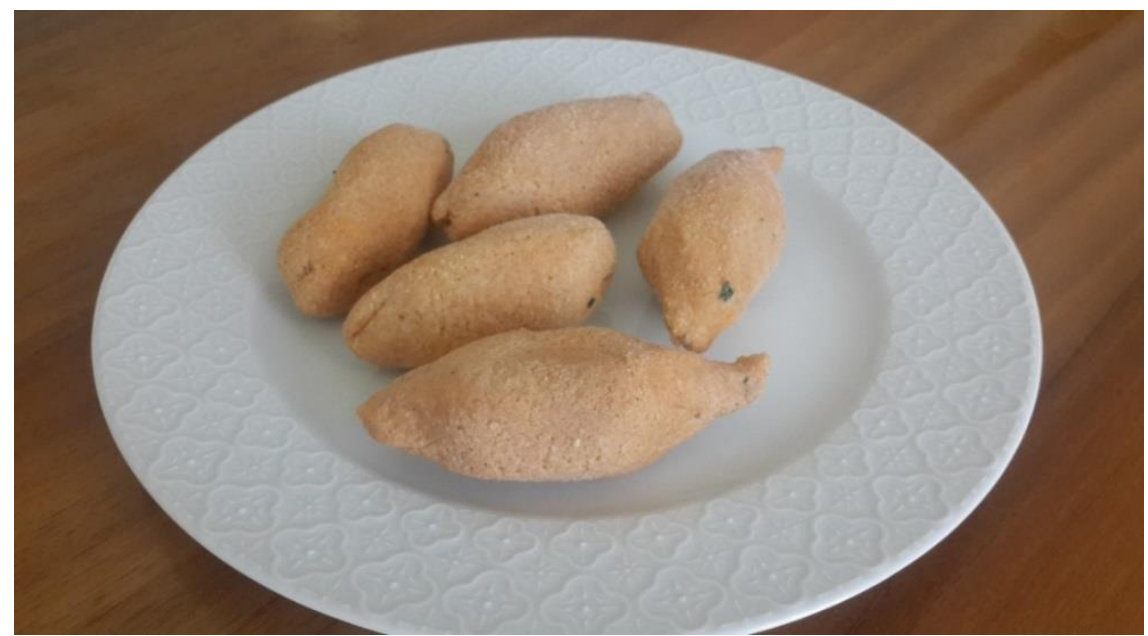

Figure 5. The frozen stuffed meatballs with rainbow trout

\section{Proximate Composition Analysis}

In the analyzes, the stuffed materials and

outer shell of the stuffed meatballs with rainbow trout were thoroughly homogenized in a Waring blender and each sample from the homogenate was analyzed in triplicate for the determination of moisture, crude ash, total lipid, and crude protein analysis, and duplicate for the determination of fatty acid composition.

Moisture and ash analysis was performed on all samples using AOAC (Association of Official Analytical Chemists, 1990) methods. The Kjeldahl method was used to determine the crude protein content (AOAC, 1990). To evaluate the lipid content, Bligh and Dyer (1959) method has been used. Fatty acid methyl esters were analyzed from extracted lipids according to the method of Ichihara et al. (1996). $4 \mathrm{ml}$ of $2 \mathrm{M} \mathrm{KOH}$ and $2 \mathrm{ml}$ of $\mathrm{n}$-heptane were added in a screw-capped glass test tube containing $25 \mathrm{mg}$ extracted oil sample. The sample heptane layer, which was mixed in a vortex for 2 minutes at room temperature and centrifuged for 10 minutes at $4000 \mathrm{rpm}$, was taken for analysis in a gas chromatography (GC) device. The fatty acid composition was determined using GC (Gas chromatography) with automatic sampling with flame ionization detector (FID) and $30 \mathrm{~m} \times 0.32 \mathrm{~mm}$ ID $\mathrm{x} 0.25 \mu \mathrm{m}$ film thickness SGE column (Perkin Emler, USA). Injector and detector temperatures were set to $220^{\circ} \mathrm{C}$ and then $280^{\circ} \mathrm{C}$ respectively. Meanwhile, the oven temperature was kept at $140^{\circ} \mathrm{C}$ for 5 minutes. Then it was brought up to $200^{\circ} \mathrm{C}$ by increasing $4^{\circ} \mathrm{C}$ every minute and from $200^{\circ} \mathrm{C}$ to 220 by $1^{\circ} \mathrm{C}$ every minute. The split application was carried out at a ratio of 1:50. Fatty acids were identified by comparing the FAME mixture consisting of standard 37 components depending on their arrival times. The results of the two GC analyses performed in the same way were expressed in GC area (\%) as mean values \pm standard deviation.

According to De Lorenzo et al. (2001), the atherogenic (AI) and thrombogenic indexes (TI) were determined as follows:

$\mathrm{AI}=(\mathrm{C} 12: 0+\mathrm{C} 14: 0+\mathrm{C} 16: 0 / n-3 P U F A+n-6$ PUFA+MUFA

$\mathrm{TI}=(\mathrm{C} 14: 0+\mathrm{C} 16: 0+\mathrm{C} 18: 0) / 0.5(\mathrm{n}-6$ PUFA $)+3 .(\mathrm{n}-3$ PUFA $)+\mathrm{n} 3 / \mathrm{n} 6$ PUFA $)$

The abbreviations MUFA and PUFA refer for monounsaturated fatty acids and polyunsaturated fatty acids, respectively.

\section{Instrumental Color Measurement}

In color measurements, The CIE $L^{*} a^{*} b^{*}$ values of samples were measured in the reflectance by a Chroma Meter Konica-Minolta CM-5 (Osaka, Japan) according to Calder (2003). Before starting the analysis, the instrument was calibrated with white and black plates.

\section{Sensory Analysis}

Color, odor, flavor, texture, and general acceptability parameters were tested to determine the sensory content of the stuffed meatballs with rainbow trout, according to Paulus et al (1979). The sensory assessment scheme was used, and the panelists were graded on a 9-point hedonic scale (1, dislike extremely to 9, like extremely). The samples were prepared in two separate ways, frying, and boiling, and then introduced to the six trained panelists for evaluation. Samples were allowed to 
dissolve for 5 hours at refrigerator condition $\left(+4^{\circ} \mathrm{C}\right)$ before cooking. The frying was performed in a Teflon-coated pot for 1 minute 40 seconds in deep oil (Fig.6). The samples were cooked in boiling water for 10 minutes during the boiling process (Fig 7). The panelists were given the samples when they were still hot.

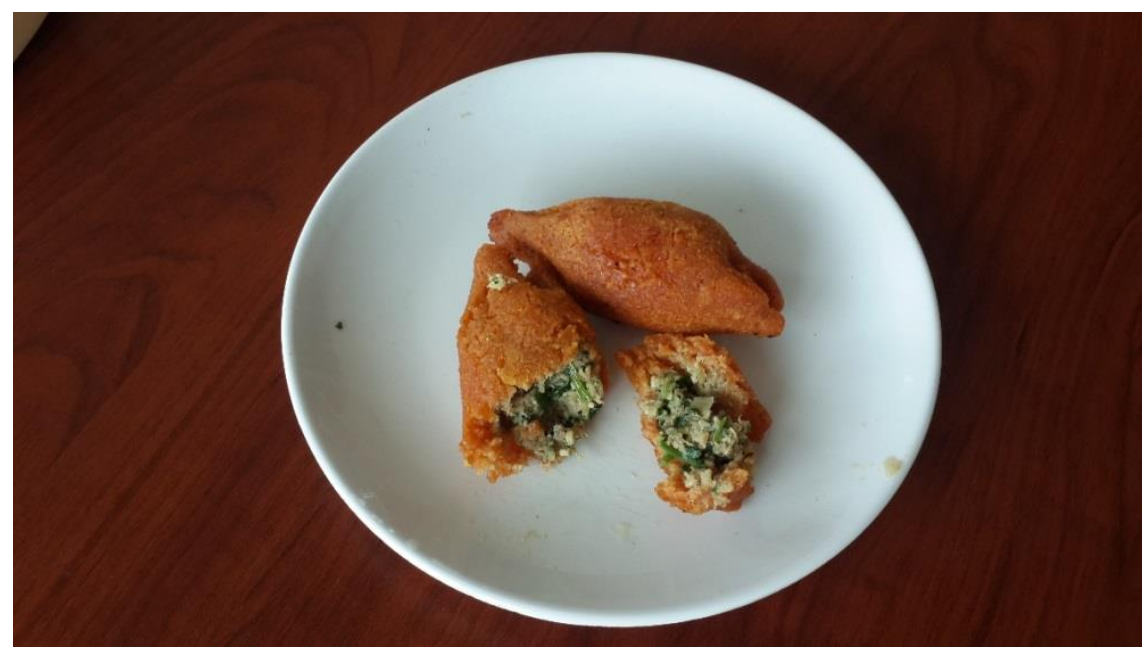

Figure 6. Fried stuffed meatballs with rainbow trout.

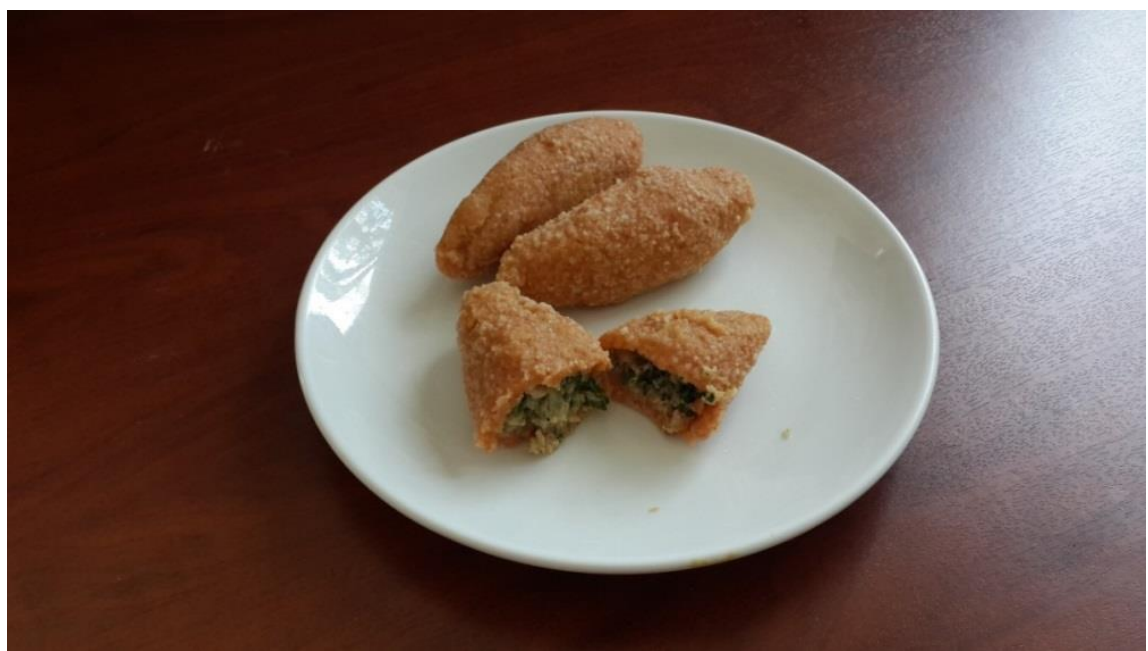

Figure 7. Boiled stuffed meatballs with rainbow trout.

\section{Statistical Analysis}

For data analysis of stuffed meatballs with rainbow trout, a one-way analysis of variance (ANOVA) was applied using the SPSS version 16 software at a 5\% confidence level, and Duncan's multiple range test at a $\mathrm{p}$-value of $<0.05$ were run to determine significant differences (Duncan, 1955).

\section{RESULTS}

\section{Proximate Composition of Raw Stuffed Meatballs with Rainbow Trout}

The amount of moisture, crude ash, lipid and crude protein of stuffed meatballs with rainbow trout were found to be $58.25 \pm 0.93 \%, 2.01 \pm 0.05 \%(4.81 \pm 0.13 \mathrm{~g} / 100 \mathrm{~g}$ dry weight $), 5.28 \pm 0.29 \%$ $(12.64 \pm 0.71 \mathrm{~g} / 100 \mathrm{~g}$ dry weight $)$ and $7.69 \pm 0.08 \%$ (18.41 $\pm 0.19 \mathrm{~g} / 100 \mathrm{~g}$ dry weight $)$, respectively (Figure 10). 


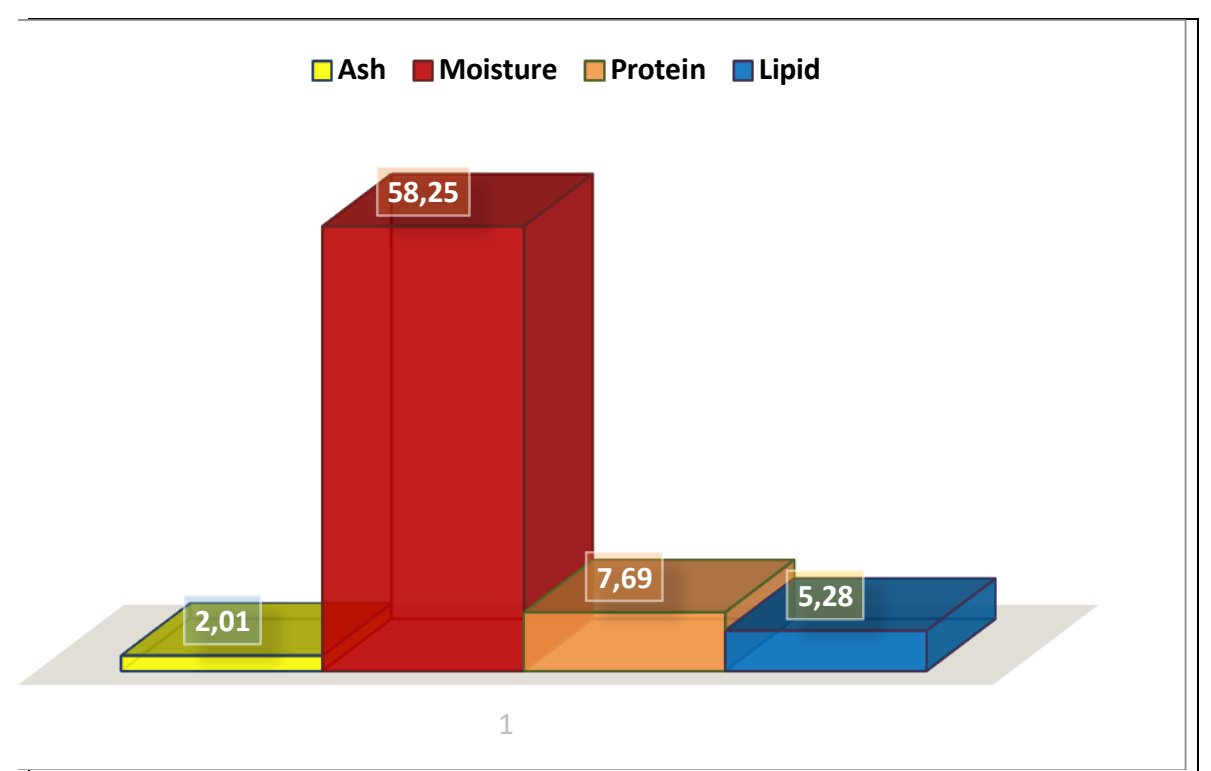

Figure 10. Proximate composition of stuffed meatballs with rainbow trout (\%, wet weight basis)

In the study, the total saturated fatty acid ( $S$ SFA), the total monounsaturated fatty acid ( $\sum$ MUFA), and the total polyunsaturated fatty acid ( $\sum$ PUFA) content of stuffed meatballs with rainbow trout were determined to be $12.52 \pm 0.23 \%, 39.11 \pm 1.27 \%$ and $43.73 \pm 1.98 \%$, respectively. The highest fatty acid among the fatty acid composition of stuffed meatballs with rainbow trout was estimated as linoleic acid (C18: 2n6) with $39.70 \pm 0.47 \%$, followed by oleic acid (C18: 1n9) with $37.86 \pm 1.18 \%$. The amount of $\mathrm{C} 18: 2 \mathrm{n} 6, \mathrm{C} 18: 3 \mathrm{n} 3, \mathrm{C} 20: 3 \mathrm{n} 6, \mathrm{C} 20: 5 \mathrm{n} 3$, and C22:6 n3 as the PUFA was found as $39.70 \pm$ $0.47 \%, 1.80 \pm 0.07 \%, 0.11 \pm 0.01 \%, 0.55 \pm 0.01 \%$ and $1.13 \pm 0.95 \%$, respectively (Table 3). Additionally, the amounts of PUFA/SFA, n3 PUFA, n6 PUFA, n6/n3, and EPA+DHA were estimated to be $3.491 .11,4.020 .34,39.71+0.24,10,880.29$, and 1.680 .48 , respectively. Furthermore, the AI and TI for dietary factors associated with cardiovascular disease were found to be 0.10 and 0.25 , respectively. 
Table 3. Fatty acid methyl esters (FAME) composition of stuffed meatballs with rainbow trout $(\%)$

\begin{tabular}{|c|c|}
\hline FAME & $\%$ \\
\hline C16:0 & $08.29 \pm 0.16$ \\
\hline $\mathrm{C} 17: 0$ & $00.06 \pm 0.00$ \\
\hline C18:0 & $03.31 \pm 0.07$ \\
\hline C20:0 & $00.31 \pm 0.01$ \\
\hline $\mathrm{C} 22: 0$ & $00.52 \pm 0.01$ \\
\hline $\mathrm{C} 24: 0$ & $00.03 \pm 0.01$ \\
\hline$\sum$ SFA & $12.52 \pm 0.23$ \\
\hline C14:1 & $0.010 \pm 0.00$ \\
\hline C16:1 & $00.28 \pm 0.39$ \\
\hline C17:1 & $00.03 \pm 0.00$ \\
\hline C18:1n-9 & $37.86 \pm 1.18$ \\
\hline C18:1n-7 & $00.02 \pm 0.01$ \\
\hline C20:1n-9 & $00.76 \pm 0.02$ \\
\hline C22:1n-9 & $00.13 \pm 0.00$ \\
\hline C24:1n-9 & $00.03 \pm 0.00$ \\
\hline$\sum$ MUFA & $39.11 \pm 1.27$ \\
\hline C18:2n-6 & $39.70 \pm 0.47$ \\
\hline C18:3n-3 & $01.80 \pm 0.07$ \\
\hline C20:3 n-6 & $00.11 \pm 0.01$ \\
\hline C20:4 n-6 & $00.01 \pm 0.00$ \\
\hline$C 20: 5 n-3$ & $00.55 \pm 0.01$ \\
\hline $\mathrm{C} 22: 6 \mathrm{n}-3$ & $01.13 \pm 0.95$ \\
\hline$\sum$ PUFA & $43.73 \pm 1.98$ \\
\hline$\sum$ PUFA/ $\sum$ SFA & $3.49 \pm 1.11$ \\
\hline$\sum$ n6 PUFA & $39.71+0.24$ \\
\hline $\bar{\sum}$ n3 PUFA & $4.02 \pm 0.34$ \\
\hline n6/n3 & $10,88 \pm 0.29$ \\
\hline $\mathrm{EPA}+\mathrm{DHA}$ & $1.68 \pm 0,48$ \\
\hline $\mathrm{AI}$ & $0,10 \pm 0.09$ \\
\hline $\mathrm{TI}$ & $0,25 \pm 0.04$ \\
\hline
\end{tabular}

The Effect of Frozen Storage on Color $(L *, a *, b *)$ Values of Stuffed Meatballs with Rainbow Trout

Table 4 shows the changes in $\mathrm{L}^{*}, \mathrm{a}^{*}$, and $\mathrm{b}^{*}$ values of stuffed meatballs with rainbow trout during frozen storage.

Table 4. Changes in $\mathrm{L}^{*}$, $\mathrm{a}^{*}$, and $\mathrm{b}^{*}$ value of stuffed meatballs with rainbow trout during frozen storage *

\begin{tabular}{cccc}
\hline \hline Months & $\mathbf{L}^{*}$ & $\mathbf{a}^{*}$ & $\mathbf{b}^{*}$ \\
\hline 0 & $58.16 \pm 0.33^{\mathrm{b}}$ & $17.51 \pm 0.79^{\mathrm{b}}$ & $26.83 \pm 0.55^{\mathrm{c}}$ \\
1 & $57.27 \pm 0.33^{\mathrm{a}}$ & $16.62 \pm 0.91^{\mathrm{b}}$ & $26.03 \pm 0.65^{\mathrm{b}}$ \\
2 & $59.47 \pm 0.67^{\mathrm{c}}$ & $16.56 \pm 0.69^{\mathrm{b}}$ & $26.99 \pm 0.28^{\mathrm{c}}$ \\
3 & $62.85 \pm 0.20^{\mathrm{e}}$ & $14.25 \pm 0.54^{\mathrm{a}}$ & $24.85 \pm 0.39^{\mathrm{a}}$ \\
4 & $60.55 \pm 0.41^{\mathrm{d}}$ & $14.82 \pm 0.41^{\mathrm{a}}$ & $29.79 \pm 0.53^{\mathrm{d}}$
\end{tabular}

*Different letters in the same column show the differences at a 0.05 significance level $(\mathrm{p}<0.05)$.

A significant increase in the $\mathrm{L} *$ values of the stuffed meatballs with rainbow trout was found at the end of storage compared to the initial values $(\mathrm{p}<0.05)$. Concerning the $*$ value, while there was no significant difference in the first two months of storage ( $p>0.05)$, this value decreased significantly in the 3rd month of storage $(\mathrm{p}<0.05)$ and this decrease remained similar at the end of storage $(\mathrm{p}>0.05)$. 
The $\mathrm{b} *$ value of raw samples significantly increased from $26.83 \pm 0.55$ at the beginning of storage to $29.79 \pm 0.53$ at the end of storage $(p<0.05)$.

\section{Changes in the Color $(\mathbf{L} *, \mathbf{a} *, \mathbf{b} *)$ Values of Frozen Stuffed Meatballs with Rainbow Trout} After Boiling

Changes in the color $\left(\mathrm{L}^{*}, \mathrm{a} *, \mathrm{~b} *\right)$ values of frozen stuffed meatballs with rainbow trout after cooked by boiling water are shown in Table 5 .

Table 5. Changes in the color $(1 *, a *, b *)$ values of frozen stuffed meatballs with rainbow trout after cooked by boiling water*

\begin{tabular}{cccc}
\hline \hline Months & $\mathbf{L}^{*}$ & $\mathbf{a}^{*}$ & $\mathbf{b}^{*}$ \\
\hline 0 & $55.19 \pm 0.51^{\mathrm{b}}$ & $15.21 \pm 0.35^{\mathrm{b}}$ & $22.62 \pm 0.31^{\mathrm{a}}$ \\
1 & $55.14 \pm 0.20^{\mathrm{b}}$ & $16.30 \pm 0.70^{\mathrm{c}}$ & $24.94 \pm 0.31^{\mathrm{b}}$ \\
2 & $51.62 \pm 0.62^{\mathrm{a}}$ & $19.62 \pm 0.50^{\mathrm{d}}$ & $29.33 \pm 0.88^{\mathrm{c}}$ \\
3 & $55.74 \pm 0.60^{\mathrm{b}}$ & $15.66 \pm 0.44^{\mathrm{bc}}$ & $25.29 \pm 0.79^{\mathrm{b}}$ \\
4 & $58.00 \pm 0.66^{\mathrm{c}}$ & $13.58 \pm 0.62^{\mathrm{a}}$ & $24.90 \pm 0.80^{\mathrm{b}}$ \\
\hline \hline
\end{tabular}

$\mathrm{L} *$ values of the samples at the beginning and the first month of storage were found to be insignificant ( $p>0.05)$, while a significant decrease was found in the second month of storage ( $p$ $<0.05)$. While the $\mathrm{L}^{*}$ values of samples were similar to the beginning and the 3rd month of storage ( $\mathrm{p}>$ $0.05)$, they showed a significant increase at the end of the storage $(\mathrm{p}<0.05)$.

In the statistical analysis performed, a significant increase was detected in the value of $a^{*}$ of samples in the first two months of storage ( $p<0.05$ ). At the end of storage, a significant decrease was found in the samples of $a^{*}$ values $(p<0.05)$.

In the samples, there was a significant increase in $b^{*}$ value of samples in the first two months of storage $(\mathrm{p}<0.05)$, while a significant decrease was found in the third month $(\mathrm{p}<0.05)$. In the 4th month, which is the last month of storage, the $b^{*}$ value in the samples was determined to be similar to the value of samples in the 1st month ( $p>0.05)$.

Changes in the Color $(\mathbf{L} *, \mathbf{a} *, \mathbf{b} *)$ Values of Frozen Stuffed Meatballs with Rainbow Trout After Frying

Changes in the color $\left(\mathrm{L}^{*}, \mathrm{a} *, \mathrm{~b} *\right)$ values of frozen stuffed meatballs with rainbow trout after frying are given in Table 6 .

Table 6. Changes in the color $\left(\mathrm{L}^{*}, \mathrm{a} *, \mathrm{~b} *\right)$ values of frozen stuffed meatballs with rainbow trout after frying *

\begin{tabular}{cccc}
\hline \hline Months & $\mathbf{L}^{*}$ & $\mathbf{a}^{*}$ & $\mathbf{b}^{*}$ \\
\hline 0 & $40.20 \pm 0.28^{\mathrm{a}}$ & $25.13 \pm 0.61^{\mathrm{d}}$ & $30.03 \pm 0.83^{\mathrm{c}}$ \\
1 & $32.95 \pm 0.84^{\mathrm{a}}$ & $19.21 \pm 0.35^{\mathrm{c}}$ & $24.92 \pm 0.76^{\mathrm{a}}$ \\
2 & $43.62 \pm 0.77^{\mathrm{b}}$ & $23.11 \pm 0.13^{\mathrm{c}}$ & $29.82 \pm 0.41^{\mathrm{c}}$ \\
3 & $50.15 \pm 0.82^{\mathrm{c}}$ & $20.32 \pm 0.58^{\mathrm{a}}$ & $28.81 \pm 0.06^{\mathrm{b}}$ \\
4 & $49.23 \pm 0.24^{\mathrm{c}}$ & $21.97 \pm 0.72^{\mathrm{b}}$ & $31.75 \pm 0.63^{\mathrm{d}}$ \\
\hline
\end{tabular}

*Different letters in the same column show the differences at a 0.05 significance level $(\mathrm{p}<0.05)$.

In this study, it was determined that the $\mathrm{L}^{*}$ value of the samples increased significantly in the first three months of storage and did not show a significant change after this month $(\mathrm{p}<0.05)$.

While a fluctuating change in the value of $a^{*}$ was observed during storage in the samples $(p<0.05)$, a significant decrease was found at the end of storage compared to the beginning value $(\mathrm{p}<0.05)$.

The $\mathrm{b} *$ value of the raw samples significantly decreased in the 1 st month of storage compared to the initial value $(\mathrm{p}<0.05)$. Then, this value increased again in the 2 nd month and was found to be similar to the initial value ( $p>0.05)$. However, the $b *$ value of the samples at the end of storage was found to be significantly higher than the initial value $(p<0.05)$. 


\section{Sensory Quality of Stuffed Meatballs with Rainbow Trout During Frozen Storage Sensory Assessment after Boiling}

The changes in sensory quality parameters of boiled stuffed meatballs with rainbow trout are shown in Table 7.

Table 7. The changes in sensory quality parameters of stuffed meatballs with rainbow trout cooked after boiling

\begin{tabular}{cccccc}
\hline \hline Months & Color & Odor & Flavor & Texture & $\begin{array}{c}\text { Overall } \\
\text { acceptability }\end{array}$ \\
\hline 0 & $8.0 \pm 1.54^{\mathrm{c}}$ & $8.6 \pm 0.51^{\mathrm{b}}$ & $8.5 \pm 0.54^{\mathrm{d}}$ & $8.3 \pm 0.81^{\mathrm{b}}$ & $8.3 \pm 0.51^{\mathrm{c}}$ \\
1 & $7.0 \pm 0.63^{\mathrm{bc}}$ & $8.0 \pm 0.63^{\mathrm{b}}$ & $8.0 \pm 0.00^{\mathrm{cd}}$ & $8.0 \pm 0.63^{\mathrm{b}}$ & $7.9 \pm 0.66^{\mathrm{c}}$ \\
2 & $7.0 \pm 0.63^{\mathrm{bc}}$ & $6.6 \pm 0.51^{\mathrm{a}}$ & $7.7 \pm 0.51^{\mathrm{bc}}$ & $7.0 \pm 0.63^{\mathrm{a}}$ & $6.8 \pm 0.75^{\mathrm{b}}$ \\
3 & $6.3 \pm 0.51^{\mathrm{ab}}$ & $6.1 \pm 0.75^{\mathrm{a}}$ & $7.3 \pm 0.55^{\mathrm{b}}$ & $6.3 \pm 0.51^{\mathrm{a}}$ & $6.0 \pm 0.00^{\mathrm{a}}$ \\
4 & $5.6 \pm 0.51^{\mathrm{a}}$ & $6.2 \pm 0.98^{\mathrm{a}}$ & $6.5 \pm 0.23^{\mathrm{a}}$ & $6.1 \pm 0.75^{\mathrm{a}}$ & $6.1 \pm 0.40^{\mathrm{a}}$ \\
\hline *Different letters in the same column show the differences at a 0.05 significance level $(\mathrm{p}<0.05)$.
\end{tabular}

According to the results of the sensory analysis, a significant decrease in the color value of boiled stuffed meatballs with rainbow trout was found at the end of storage compared to the initial value ( $p$ $<0.05)$.

The odor value in the samples evaluated by the panelists, there was no significant difference ( $p>$ 0.05 ) in the 1st month of storage ( $p>0.05$ ), and a significant decrease in the odor value of the samples occurred in the 2 nd month of storage $(\mathrm{p}<0.05)$. After this month, it was determined that there was no significant change until the end of storage ( $p>0.05)$.

In samples cooked with boiling water, the flavor score significantly decreased at the end of storage periods $(\mathrm{p}<0.05)$.

Statistically, it was determined that there was no significant difference in the texture value of the samples in the $1^{\text {st }}$ month of storage ( $>0.05$ ), while there was a decrease in this value in the $2^{\text {nd }}$ month $(p<0.05)$ and this decrease was not significant until the end of storage $(p>0.05)$.

In the samples, there was no significant difference in the overall acceptability value in the first month of storage ( $p>0.05)$, while a significant decrease was found in the third month of storage ( $p$ $<0.05)$.

\section{Sensory Assessment after Frying}

The changes in sensory quality parameters of frozen stored rainbow trout stuffed meatballs cooked after frying are shown in Table 8.

Table 8. The changes in sensory quality parameters of frozen stored rainbow trout stuffed meatballs cooked after frying *

\begin{tabular}{cccccc}
\hline \hline Months & Color & Odor & Flavor & Texture & $\begin{array}{c}\text { Overall } \\
\text { acceptability }\end{array}$ \\
\hline 0 & $8.8 \pm 0.40^{\mathrm{d}}$ & $8.1 \pm 0.75^{\mathrm{c}}$ & $8.7 \pm 0.52^{\mathrm{c}}$ & $8.5 \pm 0.54^{\mathrm{c}}$ & $8.3 \pm 0.51^{\mathrm{c}}$ \\
1 & $8.1 \pm 0.75^{\mathrm{c}}$ & $8.0 \pm 0.63^{\mathrm{c}}$ & $8.2 \pm 0.4^{\mathrm{bc}}$ & $8.0 \pm 0.63^{\mathrm{bc}}$ & $7.9 \pm 0.66^{\mathrm{c}}$ \\
2 & $7.6 \pm 0.51^{\mathrm{c}}$ & $7.5 \pm 0.54^{\mathrm{bc}}$ & $8.0 \pm 0.52^{\mathrm{b}}$ & $7.5 \pm 0.54^{\mathrm{b}}$ & $6.8 \pm 0.75^{\mathrm{b}}$ \\
3 & $6.8 \pm 0.40^{\mathrm{b}}$ & $6.5 \pm 0.54^{\mathrm{a}}$ & $7.7 \pm 0.75^{\mathrm{b}}$ & $6.5 \pm 0.54^{\mathrm{a}}$ & $6.0 \pm 0.00^{\mathrm{a}}$ \\
4 & $6.0 \pm 0.63^{\mathrm{a}}$ & $7.0 \pm 0.89^{\mathrm{ab}}$ & $6.8 \pm 0.52^{\mathrm{a}}$ & $6.0 \pm 0.89^{\mathrm{a}}$ & $6.1 \pm 0.40^{\mathrm{a}}$ \\
*Different letters in the same column show the differences at a 0.05 significance level $(\mathrm{p}<0.05)$.
\end{tabular}

According to the statistical analysis, there was a decrease in the color value in the 1st month of storage compared to the initial value $(\mathrm{p}<0.05)$, but there was no change between the 1 st month and the 2 nd month ( $p>0.05$ ). A significant decrease was observed again in the 3rd and 4th months of storage $(\mathrm{p}<0.05)$.

When the effect of frozen storage on odor value was examined, it was determined that there was a significant decrease in odor values of fried samples at the end of storage compared to the initial value $(\mathrm{p}<0.05)$. 
The sensory score for the flavor of the cooked samples by frying significantly decreased at the end of the storage time when compared to the initial value $(\mathrm{p}<0.05)$.

As a result of the statistical analysis, it was found that the texture value of the samples, which was $8.5 \pm 0.54$ at the beginning, significantly decreased to $6.0 \pm 0.89$ in the 4 th month of storage $(p<0.05)$. After these reductions, no significant change was noted ( $p>0.05$ ).

When the general acceptability values of the samples were analyzed statistically, a significant decrease was found at the end of storage compared to the initial value $(\mathrm{p}<0.05)$.

\section{DISCUSSION}

\section{Proximate Composition of Stuffed Meatballs with Rainbow Trout}

In this study, the amount of lipid $5.28 \pm 0.29 \%(12.64 \pm 0.71 \mathrm{~g} / 100 \mathrm{~g}$ dry weight $)$. Aramouni et al. (2001) found the fat content of kibbeh (stuffed meatballs) produced from ground beef as $2.36 \%$ (7.53 $\mathrm{g} / 100 \mathrm{~g}$ dry matter). It appears that the researcher did not use any oil in the filling formulation and cooking. Therefore, it is thought that the reason for this difference in the lipid content of stuffed meatballs is due to the formulation. In this study, the protein content of stuffed meatballs made from rainbow trout was found to be $18.41 \% \pm 0.19 \mathrm{~g} / 100 \mathrm{~g}$ dry matter. Aramouni et al. (2001) found that the crude protein content of stuffed meatballs produced from ground beef was $51.21 \mathrm{~g} 100 \mathrm{~g}$ dry matter. They used a high percentage of ground beef $(33.33 \%$ ground beef, $16.67 \%$ bulgur, and $50 \%$ water) in the outer shell of stuffed meatballs. It may explain the reason why the crude protein value was found higher than the value obtained in this study. Again, the same studies found the raw ash content of meatballs as $3.16 \mathrm{~g} / 100 \mathrm{~g}$ dry matter. It is seen that this value found is very close to the value found for rainbow trout stuffed meatballs (3.45 g / $100 \mathrm{~g}$ dry matter). Aramouni et al. (2001), the moisture content of the meatballs made by meatballs was $68.67 \%$ (31.32\% dry matter) higher than our findings. This is thought to be due to the different formulations to produce stuffed meatballs. In the literature review, no scientific data was found about the production of stuffed meatballs produced from fish. In this study, it is thought that the bulgur, farina, and tomato paste used in the outer mixture have a proportional effect on the nutritional composition of the stuffed meatballs made from rainbow trout.

In the present study, the highest amount of fatty acid within the fatty acid composition was estimated as linoleic acid (C18: $2 n 6)$ with $39.70 \pm 0.47 \%$, followed by oleic acid (C18: $1 \mathrm{n} 9)$ with $37.86 \pm 1.18 \%$. The amount of $\mathrm{C} 20: 5 \mathrm{n} 3$ and $\mathrm{C} 22: 6 \mathrm{n} 3$ was found to be $0.55 \pm 0.01 \%$ and $1.13 \pm$ $0.95 \%$, respectively. The total saturated fatty acid ( $\sum$ SFA) content was $12.52 \pm 0.23 \%$, the total monounsaturated fatty acid ( $\sum$ MUFA) amount was $39.10 \pm 1.27 \%$ and the total polyunsaturated fatty acid ( $\sum$ PUFA) amount was found to be $43.73 \pm 1.98 \%$. According to the results of this research, it is thought that the fatty acid compositions of rainbow trout, sunflower oil, and bulgur are used at high rates in the formulation of rainbow trout stuffed meatballs (depending on the amount of oil) are effective on the fatty acid composition of rainbow trout stuffed meatballs. Our findings are supported by previous studies mainly the fatty acid composition of ingredients used for stuffed meatballs made from rainbow trout. Öz (2009) estimated that $\sum$ SFA, $\sum$ MUFA, and $\sum$ PUFA of farmed rainbow trout were 20.74\%, 26.57\%, and 51.12\%, respectively. Bayrak and Bayraktar (1995) obtained 44.73\% linoleic acid and $41.99 \%$ oleic acid within the fatty acid composition of the sunflower oil in their study. Dağlığlu et al. (2002), who studied the fatty acid composition of 13 grain-based foods produced by Turkish companies, found that bulgur, which is used as the main material in the outer shell of stuffed meatball made from rainbow trout, consists of 18: 1, 18: 2 and 18: 3 fatty acids and they found that the 18: 2 fatty acids had the highest level with $56.8 \%$.

The fatty acid composition of dietary fats, and especially of certain specific fatty acids, is essential in human nutrition and health. A reduced saturated fat intake and an elevated PUFA-to-SFA ratio are linked to a lower risk of human coronary heart disease and increasing this ratio can be resulted in cholesterol reduction in plasma (Mcafee et al., 2010). As a result, the PUFA/SFA ratio is one of the primary criteria used to determine the nutritional content of foods' lipid fractions. This ratio was observed in this analysis to be $3,49 \pm 1.11$; a ratio PUFA/SFA above 0.4 is recommended. (Wood et al. 2004). The observed AI and TI value of $<3$ in the present study was mainly due to the n-6 PUFA content, especially 18:2 n6. These findings for TI are significant since atherosclerosis involves thrombosis. Very low levels of the above indices are prescribed in a "Healthy" diet (Ulbricht and Southgate, 1991). 


\section{The Effect of Frozen Storage on Color $(L *, a *, b *)$ Values of Stuffed Meatballs with Rainbow Trout}

Color is defined as a characteristic of light, which is both an inherent property of light and an artifact of the human eye. Physically, it is measurable in terms of intensity and wavelength. However, color as a perceptual phenomenon can be changed depending on the observer and the conditions under which color is observed (Pathare et al.,2013). Researchers state that the color of material appears only when the light from a luminous object or source is visible, or its surface is illuminated. Keskin et al. (2018) stated that color measurement should be numerically expressed in food sciences and agriculture to determine the color value precisely, accurately, and repeatably. For this purpose, different color definition models (color model) or color spaces (color spaces) have been developed to define the color value.

The HunterLab L *, a *, b* and modified Commission International de l'Eclariage (CIE) system called CIELAB, are often used in the food industry. The degree of lightness $(\mathrm{L})$, the degree of redness or greenness (+/-a), and the degree of yellowness or blueness (+/-b) is measured by the systems (Pathare et al., 2013).

Color is one of the most important quality characteristics affecting the purchasing behavior of the consumer. Many factors affect ultimate perceived color such as animal genetics, species, nutritional background, postmortem storage temperatures and time, postmortem changes in muscle, and a whole host of processing, packaging, and lighting and display variables (Hunt et al., 2012). Expected changes in colors can also indicate problems with processing or packaging. It is stated that the taste of food is generally affected by color. For these reasons, color measurement and analysis are very important to optimize the quality and value of foods (Pathare et al., 2013).

In this study, the $\mathrm{L} *$ value of the samples increased during storage $(\mathrm{p}<0.05)$. This increase in $\mathrm{L} *$ value indicates that the whiteness of the product increased during storage. This finding was different from the finding of Aramouni et al. (2001) who could not find a significant change in the $\mathrm{L} *$ value of the stuffed meatballs produced from ground beef during storage. These differences were thought to be due to the differences in the formulation of the outer shell.

In the present study, the $*$ value of samples, which indicates the storage redness, significantly decreased $(\mathrm{p}<0.05)$. Tomatoes are especially rich in lycopene content and are among the most produced, consumed, and traded agricultural products in the world. It is stated that although lycopene is the main carotenoid compound in tomato and tomato products, $\beta$-carotene is also present in these products. Calligaris et al. (2002) suggest that the loss of red color intensity in tomato products may be due to the chemical and physical changes of the carotenoids in tomatoes, especially lycopene. Cosmai et al. (2017) stated that the red color in tomato-based products has a positive effect on the appearance of the product, and the decrease in red color density during frozen storage is due to the oxidation of carotenoids, including lycopene, and the co-oxidation of enzymatic reactions. According to these results found by the researchers, the decrease in the * value, which indicates the red color intensity of the rainbow trout meatballs, may be due to the deterioration of the carotene in the tomato paste $(18.40 \%)$ in the outer shell of the stuffed meatballs during frozen storage. Similarly, a decrease in the*value of stuffed meatballs (outer shell consisting of meat and bulgur) during frozen storage was found by Aramouni et al. (2001). However, in this study, it is thought that the reason for the decrease in redness value was not due to tomato paste as in this study (the researcher did not use tomato paste in the outer shell formulation), but because the hemoglobin, which gives the red color of ground beef, is reduced during frozen storage.

In this study, a significant increase was found in $b^{*}$ values of frozen raw stuffed meatballs, cooked frozen raw stuffed meatballs with boiling water, and frying at the end of storage periods when compared to initial values $(\mathrm{p}<0.05)$. Unlike these findings, Aramouni et al. (2001), in their study, emphasized that there was no significant change in the $b *$ value of meat stuffed meatballs during frozen storage. In this study, sensory quality stuffed meatballs were evaluated in two ways: boiled and fried as common consumption type of it and fried samples were preferred by the panelists according to color and flavor. Although a significant decrease was detected in the sensory quality parameters of samples during frozen storage, it was found that they did not reach the unacceptable limit at the end of storage. One of the most remarkable changes in sensory evaluation is the decrease in color, especially in fried products. This is seen from the decrease in a $*$ value, which indicates the redness. 


\section{CONCLUSION}

In comparison to stuffed meatballs made from other meats, made from rainbow trout have been nutritionally enhanced in terms of including salmon, which play an important role in human nutrition. and can consume as an alternative value-added product for people to increase fish consumption. The instrumental color values could affect frozen storage. Although the scores of sensory quality parameters of stuffed meatballs declined during frozen storage after 4 months of storage, it was determined that it did not exceed the unacceptable limit (score <5) by the panelists.

\section{ACKNOWLEDGEMENT}

This study was supported by the University of Ordu Scientific Research Project Coordination Unit (Project Number: B-1918).

\section{REFERENCES}

AOAC (1990). Official Methods of Analysis of the Association of Official Analytical Chemists. 15th ed, Washington, DC.

Aramouni, F. M., Boyle, E. A. E., \& Yasmin, S. (2001). Chemical, microbial, and sensory evaluation of a frozen kubbee product 1. Journal of Food Quality, 24(6), 551-561.

Arslanhan, T., (2014). Adana Mutfağinin Geleneksel Lezzeti İçli Köfte. 4. Geleneksel Gıdalar Sempozyumu, $17-$ 19 Nisan, Adana

Ballı, E. 2013. Gastronomi turizmi ve adana mutfak kültürü. II Doğu Akdeniz Turizm Sempozyumu, 206.

Basaran, P. (1999). Traditional foods of the Middle East. Food Technology (Chicago), 53(6), 60-66.

Bayrak, A., \& Bayraktar, N. (1995). Ayçiçek (Helianthus annuus L.) yağının yağ asitleri kompozisyonu. Glda, 20(6), 393-396

Bligh, E. G., \& Dyer, W. J. (1959). A rapid method of total lipid extraction and purification. Canadian journal of Biochemistry and Physiology, 37(8), 911-917.

Calder, P. C. (2008). The relationship between the fatty acid composition of immune cells and their function. Prostaglandins, Leukotrienes and Essential Fatty Acids, 79(3-5), 101-108.

Calligaris, S., Falcone, P., \& Anese, M. (2002). Color changes of tomato purees during storage at freezing temperatures. Journal of Food Science, 67(6), 2432-2435.

Çolakoğlu, A. F. (2004). Farklı işleme teknolojilerinin Kızılgöz (Rutilus rutilus) ve Beyaz balık (Coregenus sp.) mikroflorası üzerine etkisi. Turkish Journal of Veterinary and Animal Sciences, 28(1), 239-247.

Cosmai, L., Caponio, F., Pasqualone, A., Paradiso, V. M., \& Summo, C. (2017). Evolution of the oxidative stability, bio-active compounds and color characteristics of non-thermally treated vegetable pâtés during frozen storage. Journal of the Science of Food and Agriculture, 97(14), 4904-4911.

Cuneo, A. (1998). DDB Wins Makeover Bid from Heins. Advertising Age, 69(33), 47.

Dağlıoğlu, O., Taşan, M., \& Tunçel, B. (2002). Determination of fatty acid composition and total trans fatty acids in cereal-based Turkish foods. Turkish Journal of Chemistry, 26(5), 705-710.

De Lorenzo, A., Petroni, M. L., De Luca, P. P., Andreoli, A., Morini, P., Iacopino, L., ... \& Perriello, G. (2001). Use of quality control indices in moderately hypocaloric Mediterranean diet for treatment of obesity. Diabetes Nutrition and Metabolism, 14(4), 181-188.

Doloksaribu, T. H., Syarief, H., Damanik, R., \& Marliyanti, S. A. (2015). The development of torbangun flourbased functional supplementary food for breastfeeding mother. International Journal of Sciences: Basic and Applied Research (IJSBAR), 1, 348-55

Dönmez, E., Salantur, A., Yazar, S., Taner, A. K. A. R., \& Yildirim, Y. (2004). Situation of bulgur in Turkey and cultivar development for bulgur. Tarla Bitkileri Merkez Araştırma Enstitüsü Dergisi, 13(1-2), 71-75

Duncan, D. B. (1955). Multiple range and multiple F tests. Biometrics, 11(1), 1-42.

Eren, A. G. F. Y., \& Sezgin, A. C. (2017). Gastronomi turizmi açisindan mersin yöresi mutfak kültürünün sürdürülebilirliği. Proceedings Book, 161.

Güler, O., Benli, S., Akdağ, G., \& Çakıcı, A. C. (2016). What is your favorite local food menu? Application of conjoint analysis on The Eastern Mediterranean cuisine of Turkey. Journal of Tourism and Gastronomy Studies, 4(3), 38-52.

Hunt, M. C., King, A., Barbut, S., Clause, J., Cornforth, D., Hanson, D., ... \& Weber, M. (2012). AMSA meat color measurement guidelines. American Meat Science Association, Champaign, Illinois USA, 61820, 1135.

Ichihara, K. I., Shibahara, A., Yamamoto, K., \& Nakayama, T. (1996). An improved method for rapid analysis of the fatty acids of glycerolipids. Lipids, 31(5), 535-539.

Işık, N., (2006). Bulgur Yemekleri. İstanbul: Alfa Basım Yayım Dağıtım A.Ş., 265s.

Kaba, N., Çorapcı, B., \& Eryaşar, K. (2014). Marine edilmiş palamut ile yapılan çiğ köftenin bazı kalite özellikleri ve besin kompozisyonunun belirlenmesi. Gıda, 39(2), 63-70. 
Keskin, M., Sekerli, Y. E., \& Gunduz, K. (2018). Influence of leaf water content on the prediction of nutrient stress in strawberry leaves using chromameter. International Journal of Agriculture \& Biology, 20, 21032109.

Khazaal, C. (2004). Methods for making Bulgur food articles and products thereof.U.S. Patent Application No. $10 / 601,114$.

McAfee, A. J., McSorley, E. M., Cuskelly, G. J., Moss, B. W., Wallace, J. M., Bonham, M. P., \& Fearon, A. M. (2010). Red meat consumption: An overview of the risks and benefits. Meat Science, 84(1), 1-13.

Öz, M. (2009). Pozantı'da yetiştirilen ve Körkün çayından avlanan gökkuşă̆ alabalıklarının (Oncorhynchus mykiss) vücut kompozisyonları ve yağ asidi profillerinin karşılaştırılması (Yüksek Lisans Tezi, Çukurova Üniversitesi Fen Bilimleri Enstitüsü Su Ürünleri Anabilim Dalı, Adana).

Ozturk, I., Karaman, S., Tastemur, B., Tornuk, F., Sagdic, O., \& Kayacier, A. (2016). Antioxidant and textural properties and aroma and fatty acid profile of meatless cig kofte, a special food in Turkey, produced by industrial processing. Journal of Food Processing and Preservation, 40(1), 48-55.

Pathare, P. B., Opara, U. L., \& Al-Said, F. A. J. (2013). Colour measurement and analysis in fresh and processed foods: a review. Food and bioprocess technology, 6(1), 36-60.

Paulus, K. (1979). Kritische Betrachtungen zur" Bewertenden Prüfung mit Skale" als einem wesentlichen Verfahren der sensorischen Analyse. LWT-Food Science and Technology, 12, 52-61.

Reddy, M. A., Elavarasan, A., Reddy, D. A., \& Bhandary, M. H. (2012). Suitability of reef cod (Epinephelus diacanthus) minced meat for preparation of ready to serve product. Advances in Applied Science Research, 3(3), 1513-1517.

Sarasin, L. G. (2000). Frozen ${ }^{\text {ee }} \mathrm{s}$ future in HMR is bright, Sarasin says. Frozen Food Age, 48,9- 42.

Saygın, Ö., \& Demirbaş, N. (2018). Türkiye'de kırmızı et tüketimi: sorunlar ve öneriler. Selcuk Journal of Agriculture and Food Sciences, 32(3), 567-574.

Şengör, G. F. Ü., \& Ceylan, Z. (2018). Türk mutfağında su ürünleri kültürü ve önemi. Süleyman Demirel Üniversitesi Eğirdir Su Ürünleri Fakültesi Dergisi, 14(4), 386-398.

TUIK, 2020. Su Ürünleri İstatistikleri. https://biruni.tuik.gov.tr/medas/?kn=97\&locale=tr

Ulbricht, T. L. V., \& Southgate, D. A. T. (1991). Coronary heart disease: seven dietary factors. The lancet, 338(8773), 985-992.

Wood, J. D., Richardson, R. I., Nute, G. R., Fisher, A. V., Campo, M. M., Kasapidou, E., ... \& Enser, M. (2004). Effects of fatty acids on meat quality: a review. Meat science, 66(1), 21-32.

Yağmur, C., A. Şahin, E. Boybek, Arıdıcı, A. (2014). Geleneksel adana yemeklerinin ve tarifelerinin belirlenmesi, enerji ve besin değerlerinin hesaplanarak beslenme ve sağlık yönünden değerlendirilmesi. 4 . Geleneksel Gidalar Sempozyumu, 17-19 Nisan 2014 Adana.

Yaman, R. (1992). Türklerde yemek yeme alışkanlıkları buna ilişkin hanımlarımızın davranış kalıpları mutfağımızda yemek pişirme usullerimizdeki farklılıklar. Dördüncü Milletler Arası Yemek Kongresi, 3-6 Eylül 1992 Konya.

Yu, B. H., \& Kies, C. (1993). Wheat products as acceptable substitutes for rice. Plant Foods for Human Nutrition, 44(1), 79-85.

Yüzgül, B. (2019, March 4). Boğaç Yüzgül: içli köfte yeni trend türk mutfak kültürü tanitim objesi olmalI. Gündemekonometre.http://gundemekonometre.com/bogac-yuzgul-icli-kofte-yeni-trend-turk-mutfakkulturu-tanitim-objesi-olmali/1831/ 